NOTES AND COMMENTS

\title{
INTERACTION OF MODIFIERS: THE EFFECT OF PALLID AND FIDGET ON POLYDACTYLY IN THE MOUSE
}

\author{
W. F. BODMER \\ Department of Genetics, University of Cambridge
}

Received I9.xii.59

The polydactylous stock used in this investigation was first described by Holt (1945). Her demonstration that its inheritance is due to a recessive gene, then poorly manifested and incompletely penetrant, was later confirmed by Fisher (1950, 1953). In fact, after selecting for improved manifestation and penetrance, Fisher was able to "classify" polydactyly well enough to show linkage with the locus leaden $(l n)$ and demonstrate the existence of linkage group XIII. Further selection has now produced a modifying genetic background which can occasionally produce polydactyly in mice that are not homozygous for the polydactyl gene.

Holt's results and the occurrence of polydactyly in Grüneberg's (1943). fidget stock strongly suggested that the manifestation of polydactyly was influenced by the genes pallid and fidget. This led Fisher to set up a systematic experiment designed to investigate the interactions. The results obtained are the subject of the present note.

The eight possible homozygotes that can be formed with two alleles at each of the three loci, pallid $(p a)$, fidget $(f i)$ and polydactyly $(p y)$, were crossed in all the 36 possible combinations, including the homozygous matings by which the stocks were maintained. Each cross produces one of the 27 genotypes that can be formed with two alleles at the three loci and results obtained for the same genotype from different crosses provide a check on whether the parental origin of $p y$ in relation to $p a$ and $f i$ has any effect on the incidence of polydactyly. This design also eliminates disturbances that are caused by the poor viabilities of pallid and fidget, as these factors do not segregate in any of the crosses. In its more extreme manifestations polydactyly now occurs to an appreciable extent on the fore as well as the hind feet. This matter will be the subject of a further communication. The data discussed below involve hind feet only.

The reciprocal crosses used provided no evidence for any maternal effect in these stocks. There were no sex differences, and the parental origin of $p y$ in relation to $p a$ and $f i$ had no effect on the incidence of polydactyly. It should, however, be pointed out that only 14 out of a total of I240 pypy mice were normal and that such a high penetrance may obscure this kind of effect.

The number of mice showing polydactyly only on the left and only on the right hind feet is shown in table $\mathrm{I}$. There is suggestive evidence that the relative proportion of mice affected on the left feet only decreases as the number of $p y$ genes increases. Data of Holt (1945), indicate a similar effect with increasing polydactyl manifestation.

Test of linear regression with the number of $p y$ genes gives

$$
\chi_{1}^{2}=3 \cdot 95 \mathrm{P} \bumpeq 5 \text { per cent. }
$$


This suggests that the left foot is less readily affected on its own than the right foot, so that with increasing polydactyl manifestation there is a decrease in the relative number of mice affected on the left foot only and a corresponding increase in the number affected on both feet.

The effects of the genes $p a$ and $f i$ on the manifestation of polydactyly are most clearly illustrated by the results from mice that are ++ and $+p y$ at the py locus. These are presented in condensed form in table 2, in which no distinction is made between different forms of polydactyly (unilateral or bilateral, etc.). With respect to pallid and fidget the only distinctions made are between genotypes homozygous at either or both of these loci, genotypes heterozygous at either or both loci and the homozygous normal controls. No further distinctions are useful because the data are inadequate to detect any specific differences there may be between the effect of pallid and of fidget. There is no doubt of the significant association of both pallid and fidget with polydactyly. Previous evidence for the effect of fidget was obtained by Wallace (r954) and by Truslove (r956).

TABLE $\mathbf{I}$

Relative incidence of polydactyly on left and right hind feet

\begin{tabular}{|c|c|c|c|c|}
\hline \multicolumn{2}{|r|}{ Genotype at $p y$ locus } & Right only & Left only & $\begin{array}{l}\text { Per cent. } \\
\text { Left only }\end{array}$ \\
\hline \multirow[t]{2}{*}{$\begin{array}{l}++ \\
+p y \\
p y p y\end{array}$} & \multirow[t]{2}{*}{ : } & $\begin{array}{r}76 \\
156 \\
62\end{array}$ & $\begin{array}{r}23 \\
33 \\
8\end{array}$ & $\begin{array}{l}23.2 \\
17.5 \\
\mathrm{II} \cdot 4\end{array}$ \\
\hline & & 294 & 64 & \\
\hline
\end{tabular}

Double heterozygotes having the $p a$ and $f$ genes from different parents show no difference in incidence from individuals heterozygous for any one of these genes. If the effect of $p a$ and $f i$ were due to a modifier linked with both $p a$ and $f$, which lie on the same chromosome, such double heterozygotes should have a polydactyl manifestation similar to that of the mutant homozygotes. It therefore seems unlikely that the effect of $p a$ and $f$ is due to linked modifiers unless there is one very close to each of these loci.

There is a greater difference in incidence between the homozygous mutants and the heterozygotes than between the heterozygotes and the homozygous normal controls. This suggests the possibility of an actual physiological interaction between the pallid and fidget phenotypic conditions and the polydactyly, as opposed to a simple dosage effect of the $p a$ and $f i$ genes.

The polydactyl incidence obtained by Holt and Wright (1946) in a cross of a pypy mouse with a fidget from Grüneberg's stock was 69 per cent., whereas in the present experiment the cross $f f i \times p y p y$ gave an incidence of only I I per cent. This contrast provides satisfactory evidence for the presence of the gene py in Grüneberg's stock. Truslove's (I956) evidence for the association of fidget and polydactyly in his stock supports this conclusion.

It is clear that the modifying genetic background, including in particular the genes $p a$ and $f$, can produce polydactyly in the absence of the major 
polydactyl gene $p y$. Such a situation may be expected to occur whenever there has been selection of a modifying genetic background favouring the expression of a particular major gene. The cross fertilisation between selffertile homostyles in natural populations of Primula vulgaris (Bodmer, I958, I 960$)$ may be an example of this effect occurring under natural conditions. The genes $p a$ and $f i$ must clearly be thought of as partially dominant when we consider them as modifiers of the incidence of polydactyly.

TABLE 2

The effect of $\mathrm{pa}$ and $\mathrm{fi}$ on the polydactyl incidence of the genotypes ++ and $+\mathrm{py}$

\begin{tabular}{|c|c|c|c|}
\hline Condition at $p a$ and $f$ loci & Polydactyls & Normals & $\begin{array}{l}\text { Per cent. } \\
\text { polydactyly }\end{array}$ \\
\hline \multirow[t]{2}{*}{$\begin{array}{l}\text { Homozygous at either or both loci } \\
\left(\frac{p a f i}{p a f i}, \frac{p a+}{p a+}, \frac{+f}{+f}, \text { and } \frac{p a f i}{p a+}\right)\end{array}$} & $\begin{array}{l}+p y \\
++\end{array}$ & $\begin{array}{l}163 \\
142\end{array}$ & \multirow[b]{2}{*}{$26 \cdot 5^{I}$} \\
\hline & Het. $\chi_{1}^{2}=\stackrel{\text { I I } 0}{0.03}$ & 305 & \\
\hline \multirow[t]{2}{*}{$\begin{array}{l}\text { Heterozygous at either or both loci } \\
\left(\frac{p a+}{++}, \frac{+f i}{++}, \frac{p a f i}{++} \text { and } \frac{p a+}{+f i}\right)\end{array}$} & $\begin{array}{l}+p y \\
++\end{array}$ & $\begin{array}{r}\text { I } 208 \\
377\end{array}$ & \multirow[b]{2}{*}{ 10.96 } \\
\hline & Het. $\chi_{1}^{2}=\begin{array}{l}195 \\
0.59\end{array}$ & I 585 & \\
\hline \multirow[t]{2}{*}{$\begin{array}{l}\text { Homozygous normal at both loci } \\
\left(\frac{++}{++}\right)\end{array}$} & $\begin{array}{l}+p y \\
++\end{array}$ & $\begin{array}{l}167 \\
230\end{array}$ & \multirow[b]{2}{*}{$2 \cdot 93$} \\
\hline & Het. $\chi_{1}^{2}=\stackrel{\mathrm{I} 2}{\mathrm{o} \cdot 09}$ & 397 & \\
\hline
\end{tabular}

The close agreement of the results from $+p y$ and ++ genotypes indicates that the gene $p y$ is still completely recessive. The only evidence for any heterozygous expression of $p y$ is in the relative incidence of polydactyly on right and left hind feet. Holt (I 945) suggested that modifiers favouring the expression of polydactyly in mice would in general be less common than suppressors of polydactyly and supported this suggestion with data obtained from outcrosses of the original stock. It seems that extensive artificial selection for the expression and penetrance of polydactyly has reversed this situation so that "enhancers" are now more common than suppressors. Nevertheless this selection has still not modified the recessiveness of the gene py. This supports Fisher's (1950) conclusion that the gene py in mice " appears to have advanced very far in the succession of changes needed to suppress its action even in the homozygote". Such a situation naturally lends itself to the possibility of rapid change in the status of polydactyly in mice providing valuable material for the study of modifiers and their specific effects on the course of development. 
I am grateful to Professor Sir Ronald Fisher, F.R.s., for providing me with his stocks of mice, allowing me access to his records and for many stimulating discussions. I would also like to acknowledge the receipt of an Agricultural Research Council Studentship during the course of this work.

\section{REFERENCES}

BODMER, W. F. 1958. Natural crossing between homostyle plants of Primula vulgaris. Heredity, 12, 363-370.

воdmer, W. F. 1960. The genetics of homostyly in populations of Primula vulgaris. Phil. Trans. Roy. Soc. B, 242, 51 7-549.

FISHER, R. A. 1950. Polydactyly in mice. Nature, London, $165,407$.

FISHER, R. A. I953. The linkage of polydactyly with leaden in the house mouse. Heredity, 7, 9 I-95.

GRÜNEBERG, H. 1943. Two new mutant genes in the house mouse. F. Genet., $45,22-28$.

HoLt, s. в. 1945. A polydactyl gene in mice capable of nearly regular manifestation. Ann. Eugen., 12, 220-249.

HOLT, S. B., AND WRIGHT, M. E. (= WALLACE). 1946. A further note on polydactyly in mice. Ann. Eugen., 13, 206-207.

truslove, G. м. 1956. The anatomy and development of the fidget mouse. 7 . Genet., 54, 64-86.

Wallace, M. E. 1954. Studies in mouse genetics. Ph.D. dissertation. Cambridge University Library. 